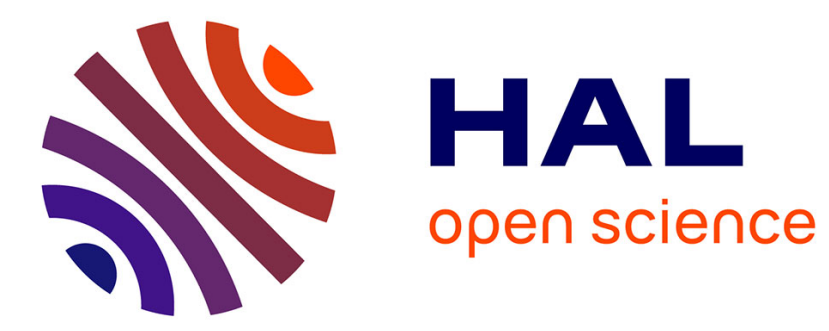

\title{
Counterfeiting as corporate externality: intellectual property crime and global insecurity
}

Simon Mackenzie

\section{To cite this version:}

Simon Mackenzie. Counterfeiting as corporate externality: intellectual property crime and global insecurity. Crime, Law and Social Change, 2010, 54 (1), pp.21-38. 10.1007/s10611-010-9246-5 . hal00607158

\section{HAL Id: hal-00607158 https://hal.science/hal-00607158}

Submitted on 8 Jul 2011

HAL is a multi-disciplinary open access archive for the deposit and dissemination of scientific research documents, whether they are published or not. The documents may come from teaching and research institutions in France or abroad, or from public or private research centers.
L'archive ouverte pluridisciplinaire HAL, est destinée au dépôt et à la diffusion de documents scientifiques de niveau recherche, publiés ou non, émanant des établissements d'enseignement et de recherche français ou étrangers, des laboratoires publics ou privés. 


\title{
Counterfeiting as corporate externality: intellectual property crime and global insecurity
}

\author{
Simon Mackenzie \\ Published online: 8 July 2010 \\ (C) Springer Science+Business Media B.V. 2010
}

\begin{abstract}
Corporate negative externalities occur when corporations place some of the costs of their profit-seeking activity onto society. This paper suggests that the current global problem of intellectual property crime is such an externality, and that it has not been recognised as such because corporations present product counterfeiting and piracy as crimes which reduce their revenue, rather than as predictable side effects of corporate production and merchandising, including branding activity, which have considerable socially deleterious consequences. It is argued that corporate actors are responsible for the socially harmful effects of the global counterfeiting problem in the following respects. Branding, advertising, and other corporate activities drive the market for goods which have a fashion value over and above their use value. While corporations 'create' this desire, they cannot prevent it being applied to the desire for fake or replica goods. Outsourcing of corporate production activities to developing countries to take advantage of cheap manufacturing and labour costs presents considerable opportunities to producers in those countries to copy and distribute the goods in an unauthorised way. Serious measures are not taken against product counterfeiters by rights-holding corporations, since market expediency dictates that the costs of counterfeiting are not so adverse to corporations to incentivise them to change their business methods. Counterfeit and pirated goods cause a range of social harms above and beyond the spuriously-costed financial damage corporate rights-holders suggest they suffer - these include the health and safety issues created by some fake goods, and the creation and maintenance of highly profitable organised crime activity in international markets for fake goods.
\end{abstract}

\section{Introduction}

Critical perspectives in criminology, sociology and law have in recent years borrowed the concept of corporate 'negative externalities' from the discipline of

This paper arose out of research undertaken for an overview of global trends in faking published as the chapter 'Fakes', in Brookman, Maguire, Pierpoint and Bennett (eds), Handbook on Crime (Willan, 2010). There is some overlap between the two texts. The core argument of this paper - of IPC as externality appears here for the first time.

S. Mackenzie $(\bowtie)$

Scottish Centre for Crime and Justice Research, University of Glasgow, Glasgow, Scotland, UK

e-mail: simon.mackenzie@glasgow.ac.uk 
economics, and brought it into popular discourse as a key way to think about questions such as responsibility, accountability, culpability and ethics in relation to some of the adverse consequences of corporate activity. Mass-market texts by authors such as Noam Chomsky, Joel Bakan, Naomi Klein, and many others, have used the idea [1-4]. Negative externalities occur when corporations place some of the costs of their profit-seeking activity onto society. The standard example of this type of corporate externality involves pollution which degrades the environment, adversely affecting public health and perhaps requiring clean-up at taxpayer expense.

The concept of a corporate externality has been relatively narrowly conceived, however, and it has clearly been in the interests of corporations to try to mask the adverse social effects of certain corporate capitalist activity. Perhaps the most effective veil for negative externalities occurs when the corporation itself is a victim-in other words when the circumstances the corporation has put in train return to adversely affect the corporate interest as well as the public interest. In this paper I suggest that the current global problem of 'Intellectual Property Crime' is such an externality, and that it has not been recognised as such because corporations present product counterfeiting and piracy as crimes which reduce their revenue, rather than as predictable side effects of corporate production and merchandising, including branding activity, which have considerable socially deleterious consequences.

I suggest that corporate actors are responsible for the socially harmful effects of the global counterfeiting problem in the following respects:

- Branding, advertising, and other corporate activities drive the market for goods which have a fashion value over and above their use value;

- While corporations 'create' this desire, they cannot prevent it being applied to the desire for fake or replica fashion goods;

- Outsourcing of corporate production activities to developing countries to take advantage of cheap manufacturing and labour costs presents considerable opportunities to producers in those countries to copy and distribute the goods in an unauthorised way;

- Serious measures are not taken against product counterfeiters by rights-holding corporations, since market expediency dictates that the costs of counterfeiting are often not so adverse to corporations to incentivise them to change their business methods;

- Counterfeit and pirated goods cause a range of social harms above and beyond the spuriously-costed financial damage corporate rights-holders suggest they suffer - these include the health and safety issues created by some fake goods, and the creation and maintenance of highly profitable organised crime activity in international markets for fake goods.

There are some immediately obvious responses to such a line. First, one might suggest that it is 'blaming the victim'-something which criminology has tended to argue vehemently against in respect of other less powerful victims. Second, one might suggest that corporate actors should not be criticised for a crime problem which is most properly seen as the enterprise of criminals over whom they have no control. The answer to both of these questions lies, I suggest, in the idea of predictable consequences. In the current criminological movement away from state definitions of 'crime' and towards efforts to achieve a broader analytical purchase on 
'social harm' $[5,6]$, the question looms large of moral liability for the predictable consequences of action. So, for example, Green and Ward have produced a compendium of 'State Crimes' which includes allegations such as against the Turkish government who are thought liable for predictable earthqudake deaths consequent upon their failure to enforce suitably stringent building regulations in an earthquake-prone area [7]. We can see, then, that powerful 'victims' can quite often be implicated in the causes of their own misfortune, and more relevant here, in the misfortune of others. As with these other analyses of the power-harm nexus, it can reasonably be argued that the current explosion of rhetoric and activity around global markets in counterfeit and pirated goods would be better oriented if it began from a platform of less ideologically-circumscribed 'crime prevention', and began to seriously acknowledge the role of corporate global business activity in creating and driving the crime problem in question.

In what follows, I will attempt to examine the theme of corporate responsibility in creating and sustaining the context of motive and opportunity which drives the counterfeit problem, and of the continuing corporate reluctance to try, in as thorough as way as possible, to mitigate the effects of that context. I will structure the argument according to the components of the argument laid out above: that corporate branding activity is instrumental in creating a market for counterfeit and pirated goods; that outsourcing of production to countries with weak legal systems and low levels of situational control on the production of fakes promotes the faking problem; that corporations do not put as much effort into anti-counterfeiting measures as they might, because it is not worth it to them, since fakes do not present a serious cost to their business models and they are therefore more concerned with mounting performative responses to suggest that they are taking the problem seriously; that the market supports the definition of the faking problem as a 'crime issue' rather than a 'business issue' as this diverts the cost of dealing with the problem onto the state and its policing functions rather than leaving the matter to be addressed at the cost of businesses themselves; and that predominantly the costs of the faking problem are borne by other actors besides the brand-holders, in particular the social costs which are imposed on the public by harmful fake products, especially in the developing world, and the organised crime activities that the attractive supply and demand dynamics of the fake trade support.

\section{White-collar crime and corporate externalities}

In the introduction to their edited book It's Legal but it Ain't Right, Passas and Goodwin observe that 'many industries generate crime externalities without necessarily committing crimes themselves' [8]. Among the activities, and associated adverse crime events, which they include by way of example are 'a variety of companies exploiting child labour and turning a blind eye to violations of human rights', and 'the illegal dumping of toxic wastes generated by chemical firms'. In respect of the latter, Szasz produced a case study which allows us to see in action the process of the social externalising of the unhappy consequences of the private drive for profit [9]. Szasz built on the distinction made by Needleman and Needleman between market sectors that are 'crime-facilitative' and those that are 'crime- 
coercive' [10]. In crime-facilitative industries, 'the criminal activity is not forced' rather it is 'unavoidable because the conditions that make it possible are necessary to the overall functioning of that industry and could not be altered without fundamentally affecting how business is conducted in that industry'. In Szasz's study, the regulation of the disposal of hazardous waste was seen to create quite foreseeable opportunities for organised crime groups to infiltrate the process as licensed but unsupervised contractors, disposing of the waste in unhealthy ways while the businesses that generated the waste and commissioned its disposal turned a blind eye.

The 'hyper-realisation' of the concept of intellectual property by way of multinational corporatisation, branding and merchandising [3], and the globalisation of production and supply, can also be studied as a crime-facilitative business practice. As we shall see, the range of crimes and harms it facilitates is diverse. In addition to being noted by criminological writers in the critical vein, such crime-facilitative business practices have also led in the more applied crime prevention literature to an analysis of 'crime as pollution' $[11,12]$, in which crime is seen as an externality of a very wide range of market-based activity:

Many agents in society (such as manufacturers and businesses) have little or no economic incentive to act in ways that reduce crime risks for others. They may, rather, save on production costs or business costs in ways that, whether inadvertently or not, serve to effectively increase the risk of crime to others [12: 152].

Among the types of 'polluters' that Farrell and Roman identify are manufacturers of goods at particular risk of theft, such as cars and mobile phones, who save on costs by excluding anti-theft devices; and retailers who fail to follow safe practices on alcohol sales, benefiting from increased sales while experiencing little of the overall cost of crime, disorder and ill-health these practices allow to develop. In this way, manufacturers, premises managers and persons 'produce targets and situations that provide criminal opportunities' but 'do not bear the crime costs to society that they produce' [11: 53]. Other examples of crime considered as a negative externality of conventional social organisation are available across a wide range of academic literature spanning disciplines, such as where increased tourism causes crime or attracts criminals [13], or the legalisation of gambling in casinos leads to thefts, burglaries, robberies, drug use, drunk driving, domestic violence, and white-collar crimes among addicted gamblers who steal from their employers, families and friends $[14,15]$.

\section{Branding and IPC}

The development of the idea of Intellectual Property Crime (IPC) has cemented the use of the language of counterfeiting beyond its more traditional use in law, where it referred to the unlawful copying of banknotes. IPC is a generic term used to describe various individual infringements contained in IP-related legislation. In the language of IPC, 'counterfeiting' is the unauthorised reproduction of branded goods, involving trademark infringement, while 'piracy' is the unauthorised copying of 
other copyright-protected works such as music and video. We will use the term 'counterfeiting' here as a shorthand reference to all types of IPC, as the technical differences between various modes of IP infringement are not key to the argument presented.

Although faking has many victims, and effects many varieties of harm, in some cases the most obvious supposed 'victims' - the buyers - do not see themselves as victims at all. Many counterfeit goods are bought quite willingly, by buyers who know they are fake. Sugden's ethnographic study of the underground economy surrounding Manchester United's brand provides good examples of this. While fake replica shirts sold to fans cause economic loss to the club, the counterfeit salesmen are viewed as 'Robin Hoods' by 'the impoverished mothers of fanatical kids from Manchester's run-down estates' who see the club that sells exorbitantly-priced originals as 'robbing bastards' [16: 251].

In such scenarios we can see crime as a form of problem solving in the Mertonian anomie vein - and the problem to be solved is, as ever, the strain created, maintained and manipulated by vested capitalist interests. IPC is an entirely predictable consequence of the market routines of branded fashion producers, with high markups, mass advertising targeted to promote brand allegiance, and global production which as we shall see attenuates control and oversight from the centre. These practices create both motive and opportunity for IPC, the co-presence of which is to some analysts the determinant of criminal activity [17]. The argument has been forcefully made, and for some time now, that advertising not only increases consumer desire for certain goods but does so by creating desires in the consumer which are often only loosely relevant to the article advertised, but which increase desire for the object by tying its social meaning to other images such as "power, wealth, status, sex, and so on' [18]. Galbraith observed the insatiable nature of such manufactured desires [19,20], and the contemporary concept of 'consumerism' includes an understanding of the tension between the desire for new possessions and their inevitable failure to satisfy on more than a short-term basis given their increasingly rapid replacement with new upgraded models, and the cycles of fashion. Perhaps the most famous contemporary journalist writing about corporations and consumerism has built on these observations to mount a critique of the power of brands themselves to take on a desirable quality, for the most part independent of the goods to which they are attached [3]. Linking brands to particular desirable lifestyle and other images has been a very deliberate strategy of our contemporary multinational corporations, precisely calculated to offer customers an opportunity to feel that their consumptive purchases have an effect on, or reflect, their idealised sense of identity. In creating brands with such power and attempting to capitalise on them by way of charging premium prices for associated products, however, IP rights-holding corporations have laid a furtile turf for a parallel market in counterfeits.

The pursuit of profit makes the faking of some items more attractive than others. Product counterfeiting is therefore structured such that the most prolific instances of faking are to be found either in markets for items which can be easily replicated in bulk at very low costs (for example CDs and DVDs burned on easily-available electronic systems) or where items are more costly or difficult to fake, in markets where these items sell for high prices (for example, aviation parts). 
Where an item is known to be fake, a consumer will pay less for it than they would for the original. Thus there arises a lure for fakers to insert their product into licit markets, to be sold as apparent originals and therefore at the highest price possible. This again invites a cost-benefit and opportunity analysis. Clearly there subsist markets in fakes where no effort is made to dupe the consumer-fake Rolexes sold in street markets in the developing world would be an example - but there is also evidence that many designer clothing and luxury item fakes are being made to increasingly high standards to aid their passing off as genuine and maximise sale price.

As well as price-maximisation, some markets display other structural pressures towards passing fakes off as genuine. In the pharmaceuticals market, end consumers are hard to reach other than through the licit market, production is tightly regulated, and production can be automated to the point that once the initial costs of setting up a factory have been met, counterfeit drugs can be produced in bulk. Fakers, as well as legitimate businesses, are attracted by the economies of scale. Thus we have seen the development of highly expertly faked packaging, security labels, holograms and other brand paraphernalia which allow fake drugs to be inserted into licit chains of supply. There have in the last few years been an increasing number of instances of such fakes being discovered having been prescribed over the counter in Western countries, and these brand-infringing and sometimes highly dangerous products confirm that fakes in this market, as in others, are often all but indistinguishable from the real thing. The profit motive here has a particularly pernicious effect: those medicines which cost the most tend to be those designed to treat very serious illness. In attracting counterfeiters with the promise of high profit margin these drugs when faked and supplied without active ingredients, or with positively harmful ingredients, can be lethal.

Counterfeiters are able to 'compete' with legitimate business in heavily regulated markets since they are not constrained with the costs of having to meet the high safety standards imposed on legitimate businesses producing items for these markets. The costs involved in meeting these safety standards are passed on to consumers by way of highly priced end products, making attractive opportunities for counterfeiters who can produce at low cost and sell at high. In some markets, like that in replacement motor vehicle parts, legitimate businesses have something of a monopoly over the production of genuine spares for their vehicles, and in addition to binding the costs of meeting safety standards into these parts, choose to exploit their monopoly by keeping prices high. These choices increase the attraction of the market for counterfeiters and enable them to easily undercut the legitimate market while still turning a good profit. Counterfeiters in spare parts markets tend to focus on the high-volume sale parts; i.e. those that are most often required by consumers [21: 10].

\section{Outsourcing}

As industrialised nations have increasingly become consumers rather than producers of goods, the locations of the production of goods destined for Western markets has shifted to 'developing' economies such as China and India, which offer labour and 
infrastructure at a low cost. Luxury goods, which were once produced by boutique, often family-owned, small businesses, are now mostly produced by multi-national corporations which bought out the small designer workshops, 'rationalised' their business methods, and shifted production to the Far East to expand production and take advantage of the lower cost of labour [22]. In respect of many businesses the process of outsourcing has been part of a corporate globalisation strategy that has fundamentally transformed the old model of firms which originated and produced their goods in the West. As well as becoming more 'global' and ethereal, these corporations are increasingly transforming themselves into middle-men rather than producers of commodities, selling on to consumers at home goods produced abroad at low cost, sometimes at very high mark-up. In some cases the big corporations own the factories where production occurs in the poor countries, while in others they buy from an independent supplier. These independent suppliers will in many cases produce goods only for one major corporate customer, blurring the line between corporate ownership and corporate supply.

This process of outsourcing of legitimate production, and the associated flow of objects from developing countries to Western consumer markets, has been mirrored by a similar flow of brand imitations and other fake goods which are produced in poor countries in order to feed demand in rich ones [23]. This approximates the 'industrialisation of faking', and in this process of illicit production we see China playing a major role. In 2006, 79\% of the IP infringing goods which were seized at EU borders originated in China [24]. As well as China, we can identify other key locations for the production of particular types of fakes: for example India is significantly implicated in the production of fake pharmaceuticals. The industrialisation of faking can be explained with reference to the legitimate market forces and production routines it mirrors. Low-paid factory owners and workers in countries which attracted outsourcing were entrusted with product designs by the large corporations who wanted their goods made cheaply, and these designs have been used as the basis for the establishment of a massive industry in fakes. This industry ranges from very poor quality imitations, which can easily be told apart from the originals, to 'fakes' which are made on the same production line as the originals, during hours of unofficial 'overtime'. These latter are therefore only 'fake' in the sense of 'unauthorised', being on all other measures identical to the originals. Somewhat ironically, the lower quality of materials now used in 'luxury' goods make them considerably easier to fake. Increasingly, aside from the brand infringement, the actual difference between some real designer goods and imitations is becoming difficult to discern, even in the case of fakes not made on the original production line.

This pattern of eastern/southern production linking with western/northern consumption is complemented by a significant uptake of the purchase of fakes in their countries of production and other developing countries. China consumes a lot of the fakes that it makes; indeed its population is mostly too poor to buy the original items. In 2001, for example, China recorded 192,000 deaths due to counterfeit medicines, and closed down 1,300 factories producing these fakes [25: 71]. While fake lifestyle drugs such as Viagra and steroids are pumped into western consumer markets where these drugs are bought in large enough quantities to make the sale of counterfeits worthwhile (HMRC reported seizures of 735,000 pharmaceuticals in 
2006), developing nations have been flooded with replicated drugs for the treatment of more serious conditions such as malaria and HIV. As mentioned above, there have been instances of fake medicinal drugs for illness being inserted into European and US markets, but to nowhere near the extent to which they have appeared in developing countries. Developing countries are characterised by high demand for these medicines combined with difficulty in paying the high prices often demanded by the pharmaceutical companies, creating opportunities to be exploited by producers of counterfeit drugs who can undercut the conventional market.

We can therefore see that there are many structural properties of contemporary market forces which create and shape the problem of the harms caused by faking on a national and international level, and that among them the outsourcing of production to economies that offer cheap production costs combined with low regulatory or practical oversight figures as one driver of the issue, with harmful effects that track the global demand for IP-protected goods.

\section{Anti-counterfeiting and the externalisation of the costs of control}

The corporate response to IPC has been somewhat underwhelming, and this can be explained with reference to the opportunity and motivation structure of the market for the production and sale of IP-protected goods. With respect to the outline presented above of outsourcing and the 'industrialisation' of faking, although the profits of IP rights-holding corporations are clearly diluted by these practices, and their brand reputations may suffer injury, ${ }^{1}$ they are so heavily dependent on legitimate foreign-outsourced production in supporting the profitability of their businesses that they, and indeed the host of international regulatory bodies charged with dealing with the faking problem, have been reluctant to make accusations or take decisive action that might embarrass the governments of supply countries. The stream of illicit goods has been seen as an unfortunate but acceptable by-product of profitable outsourced production. While it may be 'acceptable' in terms of the profit margins of corporations, it is clearly quite unacceptable when the fakes increase risks to the health and safety of consumers.

The overall record of detecting, regulating and preventing fakes has also been unimpressive. There are many reasons for this. As we have noted, there exists a tension in the social construction of the issue of IPC, whereby law enforcement agencies have tended to see industry as responsible for addressing its own IPC problems so far as possible, seeing IPC as a 'business issue' rather than a 'crime issue', while corporations keen to externalise the costs of policing have increasingly subscribed to the contrary view. Business has responded in a variety of ways to the perception of IPC as only a matter of trade-related concern. Most major corporations have taken some self-help measures, including employing anti-counterfeiting investigators and dedicated legal teams, and attempting to crime-proof their products through a range of target hardening measures. There are too many such measures to

\footnotetext{
${ }^{1}$ Note 'may': many commentators suggest that fakes do not generally harm the image of the brand but, so long as they are not dangerous, serve to promulgate the brand image and create more desire for the original product through making it more conspicuous.
} 
list here: they include such things as identification codes, holographic labels, and encryption technologies [26]. As with much situational crime prevention in practice, these measures approximate a 'sticking-plaster' approach to the counterfeiting problem - the core global economic drivers of transnational markets in fakes tend to receive little attention. The common theme of these measures is that they aim to make faking harder. Target hardening measures such as those mentioned increase the effort for fakers, since they must either break the codes in the original items before piracy can ensue, or if they are counterfeiters the intricate labels and marks must be copied as well as the product itself. The continuing rise in the problem of global IPC demonstrates that these measures cannot solve the problem of this type of crime; at least while other components of situational crime prevention theory [27] remain effectively ignored, for the risks to IPC offenders remain low compared to other criminal opportunities, and the rewards are high. Some fakers have taken up the challenge of duplicating the safety features of various consumer products, increasing the sophistication of their fakes in response to upgraded security features in the originals. Studies of offender motivation in student samples of software pirates have also revealed that some people positively relish the challenge of breaking the codes that encrypt protected material [28].

At the same time as attempting to push the major costs of policing IPC onto state law enforcement agencies, corporate brand-owners have done little to mitigate those aspects of their business routines which cause severe problems for the effective policing of the issue. There is a variety of obstacles which stand in the way of the effective regulation of counterfeit and pirated goods. Rights-holders are sometimes unable to identify fakes, resulting in abandoned prosecutions. There are several reasons for this [29]. First, as noted, some 'fakes' are actually unauthorised factory over-runs: in other words they are identical to the 'authentic' goods other than that they were not made with the consent of the rights-holder. Other than where goods are stamped with serial numbers or other systems of identification, these unauthorised products will be very hard to tell apart from the originals given that they are made from the same materials, in the same way, in the same factories. Second, supply chains have become attenuated through processes of outsourcing and subcontracting to the point that a rights-holder may not have direct knowledge of the factories involved in producing their goods. The range of sub-contractors in an outsourced production chain means there will be variations in the end products depending on where they were made, and this again makes it difficult for a rightsholder to say that a given product is fake as opposed to an authorised product suffering incidental variation from the core design. Third, parallel trading results sometimes in goods with different specifications being designed for markets in different countries. This means that where, for example, a UK subsidiary of a multinational company is approached by Trading Standards to pass judgement on whether a seized product is counterfeit, they may not have the information to decide whether it is a fake or a legitimate design from a different market. Counterfeiters can abuse this uncertainty by claiming their fakes to be parallel imports, setting off timeconsuming and costly investigations to determine whether this is the case. As Vagg and Harris note [29], where seized goods do turn out to be legitimate parallel imports, Trading Standards can be sued for wrongful seizure, and consequent loss of earnings. Where Trading Standards bear the risk of these legal recriminations rather 
than the rights-holder who mistakenly claimed the goods to be fake, they are best advised to err on the side of caution when there is doubt over the legitimacy of goods. This makes zero-tolerance approaches to IPC difficult to enforce in practice.

Public education strategies are also in play as forms of intervention in the market in counterfeits, in keeping with the underlying philosophy of the Market Reduction Approach [30]. This is the idea that by reducing the uptake of illicit purchase opportunities, a reduction in economic incentives will occur for those trafficking counterfeits which will ultimately make its way back up the chain of supply to discourage the manufacturers of counterfeits at source. Public education continues to be thought to play a leading role in discouraging consumers from purchasing illicit 'bargains'. It is telling that these approaches are so prevalent - the problem is (re) framed as one where consumers are to blame for their consumptive choices; the problem would be solved if only they could be persuaded to buy the right things from the right people. The predictable and rational consequence of the branding and advertising activities undertaken by corporate labels tend not to feature in business or law enforcement thinking about anti-counterfeiting strategies - that where similar goods are offered at a fraction of the price they will be attractive to consumers who have been exposed to the forces that create in them the desire for the brand, and for many of whom a replica is good enough.

Various strategies of intervention in the educative vein have been attempted, including alerting consumers to the idea that their seemingly relatively innocuous purchases of copied DVDs may be funding serious organised crime, and shaming purchasers by associating their actions with 'real' crime or otherwise trying to attach social stigma to such purchases. An example of the 'it's a crime' approach is the latest addition to front-end DVD material: 'you wouldn't steal a car... etc; so don't buy a counterfeit DVD'. An example of the social stigma approach is the 'don't be a Knock-off Nigel' campaign which has recently been rolled out nationally in the UK on television and in cinemas. The problem with the 'it's a crime' approach is that surveys reveal that around $80 \%$ of the public now know counterfeiting and piracy are criminal. Unfortunately the hitherto-assumed next step-that this knowledge would lead them not to purchase counterfeit goods - has not in fact materialised to a satisfactory degree. Thus we see the new strategy emerging, moving from appeals to the legal and moral status of the act of theft itself, to appeals to social stigma and attempted control through embarrassment. Legal/moral strategies have been rendered less than fully effective by the fact that consumers are often quite able to neutralise feelings of wrongfulness with reference to the nature of the perceived victim (corporate media making large profits) and the impression that the property rights gifted by IP laws may be more artificial and more obviously 'constructed' than more conventional property rights. The hope now is that the possibility of the taint of social stigma is less easily neutralised than moral/legal knowledge concerned with the act of theft, and that people will want to avoid taking on the identity of a 'Knockoff Nigel'. The success of this strategy remains to be seen.

Other recent developments include marginally less patronising plans to attempt to influence purchasing routines by educating the public as to the nature of the harms counterfeits cause; but again these are somewhat hamstrung by the need to frame counterfeits as defective products (which is not always true), to highlight physical injury to consumers (which is only a risk in relation to certain categories of fake) and 
to suggest links to organised crime (a term never used in its more empirically nuanced sense of networked entrepreneurs and grey markets in this discourse), while strategically ignoring the driving force behind the development of the concept of IPC (businesses' lost profits) which remains a harm to which the public appear consistently unsympathetic. These appeals are, in my analysis, to the key externalities of corporate activity in creating markets in branded goods. It is interesting that these predictable outcomes of IP protection in brand marketsparallel or intermixed flows of defective or dangerous goods, and organised criminal activity - are now being highlighted by policing and trade organisations as reasons not to buy fakes, when their production is so closely tied to the social and economic structures and forces created by legitimate markets that they are, in effect, an inevitable output of those legitimate markets.

\section{Externalisation of harm}

Let us look more closely at the issue of dangerous or defective counterfeits, since this is where we find much of the externalised cost of the corporate merchandising of IP-protected goods. Medicines, industrial machine parts, auto and aviation parts, food and beverage products (including alcohol) and the like which misleadingly purport to be made by a certain manufacturer are sometimes of significantly lower quality than the originals, and can pose serious health risks to users. So contrary to the view that IP infringement is primarily a matter of economic loss for the brandholder, the practice can involve considerable risk to the health and safety of the public [31]. For example, diethylene glycol (anti-freeze) in counterfeit medicines has killed hundreds of people in a series of tragedies in Haiti, Nigeria and Bangladesh [32]. In 2002 the International Federation of Pharmaceutical Manufacturers Associations estimated that $40 \%$ of antimalarial drugs in Southeast Asia did not contain an active ingredient [25: 71]. As well as causing physical or psychological harm by underperforming or containing harmful substances, counterfeit drugs containing under-dosages can foster resistance to the active ingredients, compounding the problems experienced by developing countries suffering epidemics [33].

Estimating the harm caused by the counterfeiting problem is difficult. There is a general dearth of reliable statistical evidence on most aspects of counterfeiting. Fakes in all markets are notoriously under-reported. Many fakes will never be discovered, even when they cause accidents: the sorts of forensic investigations which might link an aircraft crash to a fake part, or a death to a fake medicine, are not usually undertaken for more common accidents and injuries, such as motor vehicle crashes, let alone where the fake in the end does its job well enough and does not cause an accident. Where one receives an electrical shock from a faulty appliance it will be more likely thrown away than examined to see if it is fake. It might, if reported, be kept as data by a trading standards body, but the various processes of attrition in the likelihood of such reporting gives an indication of just how partial a view of the market will be held in such datasets. Many fakes are bought by willing buyers and will therefore not lead to reporting, and even some buyers who are duped into buying a fake will not draw attention to the fact for fear of seeming stupid or, in the case of specialist markets like the art market, having 
their expertise called into question. In a 1999 report on the counterfeiting of medicines, the WHO made a point of calling attention to the reluctance of pharmaceutical companies to report the known presence of counterfeits in the market [34]. While the companies claim this is to avoid consumer alarm, it has been alleged that it is more likely fuelled by a desire to protect their brand image. Recent statements have been made by trade bodies such as the Royal Pharmaceutical Society to the effect that companies are now encouraged to make their knowledge public [35].

There are various estimates available of the size of the counterfeit segments of a range of markets. Given the risk to health, and sometimes life, some of these illicit markets represent, many of these estimates are very worrying. They tend to be made in the form of unsupported statements, however, with reports referencing other reports without making clear the precise source of the estimates or the methodology and data used to arrive at them. UNICRI produces several such estimates in its latest report on counterfeiting, asserting for example that counterfeits may make up as much as $10 \%$ of the legal market for aircraft parts in the USA, a similar percentage of the motor vehicle parts market in the UK, and in relation to pharmaceuticals, around $1 \%$ in developed countries, 10 to $30 \%$ in Africa, Asia and parts of Latin America, more than $20 \%$ in ex-Soviet republics, and more than half of all drugs sold on the internet [25: 55, 58, 68-69].

There is also the problem that many estimates of the global trade in fakes are produced by interest groups representing the legitimate trade. These groups can be suspected of not producing especially reliable figures: they are usually not expert in research methodologies, they sometimes have an interest in inflating the figures (to suggest the problem is worse than it is and exert pressure for governmental action) and sometimes in deflating them (to suggest their market is resilient in the face of fakes, and that consumers can be assured that almost all products in a given market are genuine).

Some figures and other data have been produced which are more than just rough estimates, however. These tend to be from case studies and can give us accurate local pictures of the scale and effects of some harmful faking. For example, a multinational survey in 2004 found 53\% of antimalarials in Southeast Asia to be fakes containing incorrect levels of the active ingredient [36]. Seizure statistics are also available, and can give us a partial indication of the scale of the problem. We can briefly review these here in terms of global, European and UK trends.

\section{Global trends}

The OECD in June 2007 published a preliminary executive summary (the full report on which it is based remains unpublished at the time of writing) which used data from customs seizures in OECD countries to estimate that the global trade in counterfeit and pirated products 'could have been up to USD 200 billion in 2005' [37] which would represent about $2 \%$ of world trade. We need yet more caveats here: extrapolated seizure statistics will not include domestically produced and consumed counterfeit goods (i.e. those not trafficked transnationally), or digital products distributed on the internet. In 1988/89 the International Chamber of Commerce had estimated the IPC economy at $2-4 \%$ of world trade, and by 2002 its 
new Counterfeiting Intelligence Bureau estimated the illicit trade had risen to 5-7\% of world trade [38]. Given other available information it seems unlikely that the global IPC trade has fallen between 2002 and now; it is more likely that, as we have said, the significant exclusions from the OECD's recent $2 \%$ estimate would raise that figure to an unknown degree.

\section{European trends}

In the EU, Regulation 1383/2003 (Customs Actions Against Goods Suspected of Infringing Intellectual Property Rights) sets the relevant regulatory framework for the enforcement of border measures and Regulation 1891/2004 contains provisions for implementation. Different approaches are taken to the implementation of enforcement measures at borders by different Member States, however, as they seek to apply these Regulations in terms of their own legal processes. These differences in law and application have been thoroughly documented [39]. Customs seizure statistics are published annually in an EU report; the latest version at the time of writing is for 2007 [24]. It is important to remember that these trends cannot inform us of the level of counterfeit manufacturing, transit or purchase, but only reveal the aggregated activities of customs in EU Member States.

The number of cases (i.e. the number of seizures, rather than the number of goods themselves) has increased year on year from 5,056 in 2001 to 43,671 in 2007. The number of articles tends to fluctuate quite wildly: for example in the last 3 years the figures have been 76 million (2005), 128 million (2006), and 79 million (2007). These variations are likely to some extent to be an artefact of customs activity: in 2007 for example, more seizures than previously were made in air and postal freight, producing the pattern of higher cases in that year but less articles seized, due to the small size of these types of shipments. The drop in articles seized in 2007 was due to significant falls in intercepted counterfeit cigarettes and CDs/DVDs, and the overall drop in that year thus disguises a rise in the number of articles seized in every other type of counterfeit, including a near $100 \%$ increase in toys and a $50 \%$ increase in medicines. Although around a third of cases of seizure are made in relation to passenger traffic, due to the far greater amount of goods per commercial shipment, $95 \%$ of all items seized were from interceptions of commercial traffic in 2007. Most seizures were of trademark infringing goods (92\%), with 5\% being patent infringements (mostly electronic equipment such as MP3 and DVD players), $2 \%$ copyright infringements (mostly CDs and DVDs, as well as items containing protected images such as well-known comic figures), and $1 \%$ design right infringements (mainly clothing, toys and cellphone accessories).

\section{UK trends}

The number of people sentenced for IPC has fluctuated over the last decade, with a notable rise since 2002. There has been a corresponding rise in the use of imprisonment for these offenders. In 2002, 441 people were sentenced in the UK for IPC, with 25 imprisoned. By 2005, the number of people sentenced had more than doubled to 995, with 195 imprisoned [40: 73]. The increasing use of imprisonment for IP criminals suggests an increase in the seriousness with which IPC is viewed by 
the criminal justice system, and it therefore seems likely that a proportion of the dramatic rise in IPC sentences since 2002 is due to increased law enforcement concern with the matter rather than a rise in the incidence of the crimes themselves.

The IP Crime Group also surveyed all Trading Standards services in the UK (although not all responded, rendering the data only a partial picture), in relation to their activities in 2006. By far the highest numbers of counterfeit goods seized by responding Trading Standards services (by unit) in 2006 were DVDs and software (217,274 items), followed by clothing $(116,594)$. The next largest categories to these two were cigarettes (13,200 items) and CDs (12,719 items). The street value of the clothing seized was estimated at around $£ 2.5$ million, as against $£ 1.1$ million for the DVDs and software.

What does the future hold for IPC trends? Fraud has been predicted to rise to be 'the crime of the $21^{\text {st }}$ century' due to the interplay of a range of factors, chief among them the new opportunities for this type of crime presented by social and technological developments, and the low likelihood of apprehension [41]. Not all IPC is fraudulent, but we might equally say that social (especially the growing importance of branding to consumers) and technological (especially the growth in copying technology) factors, as well as the global economic trends mentioned, have increased the opportunities for criminal gain in this field, and the likelihood of apprehension is low. Unless these factors change significantly we might reasonably expect the growth in IPC to continue.

As the above statistics imply, as well as physical harms counterfeit goods cause financial loss to the companies that hold the IP rights to the goods in question, and this cost of 'victimisation' would presumably be the main corporate argument against the position outlined here that most of the costs of counterfeiting are externalised by brand holders. That argument seems to find stronger support in relation to some commodity markets than others. For example, the British Phonographic Industry estimated physical music piracy cost the industry $£ 165$ million in lost retail sales in 2006 and it is well known that the music industry has lately been feeling quite severely the effects of internet file-sharing.

Yet even in relation to an industry which is famous for suffering the effects of IPC, there are good reasons to question the corporate estimate of the scale of loss. Generally, we can observe that businesses and anti-counterfeiting associations representing trade interests routinely inflate the amount of financial loss represented by brand copies. In their argument, a consumer who purchases a counterfeit product has deprived the brand-holder of a legitimate sale. Yet it is not correct to say that a consumer who chose to buy a counterfeit would otherwise have bought the original version. This is particularly the case where, as is usual, the original is priced at a point significantly higher than the fake. It may be that a fake DVD bought at $£ 2$ represents a lost legitimate sale at $£ 10$, but it may very well not, and the logic becomes even more stretched if the sale is of a fake Louis Vuitton bag at $£ 10$ where the original costs $£ 2,000$. In the latter sort of sale it is more likely that the counterfeit represents no direct financial loss to the company whatsoever, under the 'replacement' argument at least, as almost all buyers at $£ 10$ would not have bought at $£ 2000$, and almost all buyers at $£ 2000$ would not want a $£ 10$ fake. Further, even if the 'replacement' argument were thought a correct analysis, the true financial loss to the brandholder would have to be calculated using only the profit element 
represented by sales, rather than the full market value of the items sold. And of course internet music piracy generally involves no or negligible cost to the downloader, who would never otherwise have bought many of the albums in their new collection.

In relation to other similarly-costed estimates of the harm caused by counterfeits, the Business Software Agency conduct an annual Global Software Piracy Study which in its latest sweep (2007) estimated 38\% of software used worldwide to be pirated, representing losses to industry, they say, of USD 48 billion. The median piracy rate was $61 \%$ meaning half of the 108 countries in the survey had a software piracy rate of $61 \%$ or higher [42]. In terms of 'internalised' costs, poor quality brand counterfeits may deplete consumer faith in markets generally, and the ease with which counterfeiters can copy new designs may discourage businesses from research and development [43]. Against this argument that faking has an adverse effect on innovation through discouraging $\mathrm{R} \& \mathrm{D}$, there is a more critical argument that the enforcement of IP rights stifles invention [44, 45] such as by restricting the capacity of some product designers to build on and improve the ideas of others. While, therefore, the World Intellectual Property Organization (WIPO) considers IP protection an essential cornerstone of 'all social, economic and cultural development' [46: 41], this is a somewhat dubious, if widely accepted, position.

There are clearly therefore both substantial internalised and externalised costs associated with the problem of IPC, but while the internalised costs are felt by rightsholders as financial losses, the negative externalities of the legal trade in IP-protected goods are experienced by wider society as a range of harmful social outcomes. We can also of course identify 'positive' externalities in which IPC is not experienced by consumers as a social harm-the very high level of software piracy in the global survey mentioned, for instance, will include many happy users of pirated software who are pleased to have a product that is on all measures identical to the original other than being unauthorised. Still, the internalised corporate costs and positive externalities of IPC should not divert analysis from the negative externalities we have identified, which remain a distinctive corporate contribution to 'crime as pollution' and to contemporary global insecurity.

\section{Conclusion}

The above review of research, statistics, and interventions in relation to product counterfeiting and piracy shows that the issue is important in terms of the social harm it represents, that it is a growing problem, and that it is not effectively regulated. In large part the problem of poor regulation results from IPC's 'hot potato' status - the police see business as best placed to deal with it, and businesses do not want to divert their profits into setting up larger internal anti-counterfeiting units than are absolutely necessary to suggest to outsiders that they are taking the issue seriously. The problem falls into a liminal zone of regulation where the most relevant body (in the UK) is the local trading standards office, staffed by non-police personnel and exercising limited powers with relatively little resource. The economic downturn has led to global corporations shedding jobs, and units such as anticounterfeiting teams (or often persons) which are not at the front-line of profit 
generation are under threat (a personal communication to the author from a police source confirms this - a major commercial player in the UK has in the summer of 2009 made its head of anti-counterfeiting redundant, with no plans to replace him). If the fight against organised crime is really going to involve business co-operation in combating international markets in counterfeit goods, the consumptive attitude of corporations towards policing and their reluctance to take costly steps to mitigate the negative externalities of their business methods, will need to be overcome.

What are the implications of the above analysis for criminological theory? The social harm perspective has found such wide acceptance that it can now be found not only in the critical left, but also in the 'mainstream' of criminology-e.g. the 'crime as pollution' analysis mentioned above-as well as in practitioner approaches to criminal justice - e.g. the current move in the UK towards a social harm perspective in the risk assessment of organised crime, and the performance management of the specialist police who engage with it [47]. Once one begins to 'take harm seriously' [5], previously narrowly-conceived matters of criminal culpability are seen as only a rather artificially delimited part of a much larger tapestry of harmful 'effects', and also as is argued here, 'side-effects'. One productive route for criminology might be to explore the further integration of critical and applied perspectives which has informed the present analysis. The 'crime as pollution' argument, based as it is in an economic perspective and with an understanding of the externalities of legal or borderline-legal activities, has been offered by Farrell and Roman as a tool of analysis to extend the (mainly situational) crime prevention approach [12] by way of using 'market-based incentives' to encourage business to accept the cost of crimeproofing their products, such as by arranging for them to suffer financial penalty if they do not. Yet such a perspective also seems quite amenable to application as a framework for understanding the drivers of some of the pressing contemporary global security issues where these are the widely-felt externalities of international economic organisation and routines. Here, product crime-proofing might not be sufficient to unwind the criminogenic situation created by IP-related global corporate business practice. Neither would taxes on business equivalent to an estimation of the externalised costs seem appropriate, as they would be passed on to consumers by way of rises in the cost of the branded goods, and it is this high cost which is implicated in the creation of the problem of IPC in the first place. Still, the integration of the practical thinking of crime prevention specialists with the political economies of globalised capitalist production devised in the analyses of critical scholars lead us to observe that if crime is an externalised form of 'pollution', market forces pollute on a scale generally unrecognised.

\section{References}

1. Bakan, J. (2004). The Corporation: the Pathological Pursuit of Profit and Power. New York: Free Press.

2. Chomsky, N. (1999). Profit Over People: Neoliberalism and Global Order. New York: Seven Stories Press.

3. Klein, N. (2000). No Logo: Taking Aim at the Brand Bullies. Toronto: Knopf Canada.

4. Klein, N. (2007). The Shock Doctrine: the Rise of Disaster Capitalism. Toronto: Knopf Canada. 
5. Hillyard, P., Pantazis, C., Tombs, S., \& Gordon, D. (Eds.). (2004). Beyond Criminology: Taking Harm Seriously. London: Pluto Press.

6. Friedrichs, D.O. and Schwartz, M. (Eds.) (2007). Special Issue of Crime, Law \& Social Change. Vol. 48: Iss. $1 / 2$.

7. Green, P. J., \& Ward, T. (2004). State Crime: Governments, Violence and Corruption. London: Pluto Press.

8. Passas, N., \& Goodwin, N. R. (Eds.). (2004). It's Legal but it Ain't Right: Harmful Social Consequences of Legal Industries. Ann Arbor: University of Michigan Press.

9. Szasz, A. (1986). Corporations, Organized Crime, and the Disposal of Hazardous Waste: an Examination of the Making of a Criminogenic Regulatory Structure. Criminology, 24(1), 1-28.

10. Needleman, M. L., \& Needleman, C. (1979). Organizational Crime: Two Models of Criminogenesis. Sociological Quarterly, 20, 517-528.

11. Roman, J., \& Farrell, G. (2002). Cost-benefit Analysis for Crime Prevention: Opportunity Costs, Routine Savings and Crime Externalities. In N. Tilley (Ed.), Evaluation for Crime Prevention (Criminal Justice Studies Vol. 14) (pp. 53-92). Monsey: Criminal Justice Press.

12. Farrell, G., \& Roman, J. (2006). Crime as Pollution: Proposal for Market-based Incentives to Reduce Crime Externalities. In K. Moss \& M. Stephens (Eds.), Crime Reduction and the Law. Routledge: Abingdon.

13. McPheters, L., \& Stronge, W. B. (1974). Crime as an Environmental Externality of Tourism: Miami, Florida. Land Economics, 50(3), 288-292.

14. Kindt, J. W. (2004). The Costs of Legalized Gambling: An Economic Approach. In N. Passas \& N. Goodwin (Eds.), It's Legal but it Ain't Right (pp. 115-137). Ann Arbor: Michigan University Press.

15. Das, S. (Ed.) (1994). Casinos in Florida: an Analysis of the Economic and Social Impacts. Tallahassee: Office of Planning and Budgeting, Florida Office of the Governor.

16. Sugden, J. (2007). Inside the Grafters' Game: an Ethnographic Examination of Football's Underground Economy. Journal of Sport and Social Issues, 31(3), 242-258.

17. Pawson, R., \& Tilley, N. (1997). Realistic Evaluation. London: Sage Publications.

18. Crisp, R. (1987). Persuasive Advertising, Autonomy and the Creation of Desire. Journal of Business Ethics, 6(5), 413-418.

19. Galbraith, J. K. (1958). The Affluent Society. Boston: Houghton Mifflin.

20. Galbraith, J. K. (1967). The New Industrial State. Boston: Houghton Mifflin.

21. Brut, J.-P. (1999). Car Parts Counterfeiting. In R. E. Kendall (Ed.), International Criminal Police Review: Special Issue on Counterfeiting. Lyon: ICPO/Interpol.

22. Thomas, D. (2007). Deluxe: How Luxury Lost its Lustre. New York: Penguin.

23. Grossman, G. M., \& Shapiro, C. (1989). Foreign Counterfeit of Status Goods. Quarterly Journal of Economics, 103, 79-100.

24. EU Taxation and Customs Union (2007). Report on Community Customs Activities on Counterfeit and Piracy: Results at the European Border-2007. European Commission website at http://ec.europa.eu/ taxation_customs/resources/documents/customs/customs_controls/counterfeit_piracy/statistics2007.pdf (version current at 23 July 2009).

25. UNICRI (2007). Counterfeiting: a Global Spread, a Global Threat. United Nations Inter-regional Crime and Justice Research Institute.

26. Piquero, N. L. (2005). Causes and Prevention of Intellectual Property Crime. Trends in Organized Crime, 8(4), 40-61.

27. Clarke, R. V. (1992). Situational Crime Prevention. New York: Harrow and Heston.

28. Sims, R. R., Cheng, H. K., \& Teegen, H. (1996). Toward a Profile of Student Software Pirates. Journal of Business Ethics, 15, 839-849.

29. Vagg, J., \& Harris, J. (2000). False Profits: Why Product Counterfeiting is Increasing. European Journal on Criminal Policy and Research, 8, 107-115.

30. Sutton, M. (1998). Handling Stolen Goods \& Theft: a Market Reduction Approach. Home Office Research Study 178. London: Home Office.

31. Yar, M. (2005). A Deadly Faith in Fakes: Trademark Theft and the Global Trade in Counterfeit Automotive Components. Internet Journal of Criminology, www.internetjournalofcriminology.com.

32. Hanif, M., Mobarak, M., Ronan, A., Rahaman, D., \& Donovan, J. (1995). Fatal Renal Failure Caused by Diethylene Glycol in Paracetamol Elixir: the Bangladesh Epidemic. British Medical Journal, 311, 88-91.

33. Morris, J., \& Stevens, P. (2006). Counterfeit Medicines in Less Developed Countries: Problems and Solutions. London: International Policy Network. 
34. World Health Organization. (1999). Guidelines for the Development of Measures to Combat Counterfeit Drugs. Geneva: WHO.

35. Cockburn, R., Newton, P.N., Agyarko, E.K., Akunyili, D., and White, N.J. (2005). The Global Threat of Counterfeit Drugs: Why Industry and Governments Must Communicate the Dangers. PLoS Medicine, 2(4)

36. Dondorp, A., Newton, P., Mayxay, M., Van Damme, W., Smithuis, F., Yeung, S., et al. (2004). Fake Antimalarials in Southeast Asia are a Major Impediment to Malaria Control: Multinational Crosssectional Survey on the Prevalence of Fake Antimalarials. Tropical Medicine \& International Health, $9(12), 1241$.

37. OECD (2007). The Economic Impact of Counterfeiting and Piracy: Executive Summary. Organisation for Economic Co-operation and Development website at http://www.oecd.org/dataoecd/13/12/ 38707619.pdf (version current at 23 July 2009).

38. Hetzer, W. (2002). Godfathers and Pirates: Counterfeiting and Organized Crime. European Journal of Crime, Criminal Law and Criminal Justice, 10(4), 303-320.

39. Vrins, O., \& Schneider, M. (Eds.). (2006). Enforcement of Intellectual Property Rights Through Border Measures: Law and Practice in the EU. Oxford: Oxford University Press.

40. IP Crime Group. (2007). Intellectual Property Crime Report 2007. Newport, South Wales: UK-IPO.

41. Albanese, J. S. (2005). Fraud: the Characteristic Crime of the 21st Century. Trends in Organized Crime, 8(4), 6-14.

42. BSA (2008). Fifth Annual BSA and IDC Global Software Piracy Study. Business Software Alliance website at http://global.bsa.org/idcglobalstudy2007/studies/2007_global_piracy_study.pdf (version current at 23 July 2009).

43. International Chamber of Commerce (2005). Intellectual Property: Source of Innovation, Creativity, Growth and Progress. ICC website at http://www.iccwbo.org/uploadedFiles/ICC/policy/intellectual_ property/Statements/BASCAP_IP_pub.pdf (version current at 23 July 2009).

44. Lessig, L. (2001). The Future of Ideas: the Fate of the Commons in a Connected World. New York: Random House.

45. Moohr, G. S. (2003). The Crime of Copyright Infringement: an Inquiry Based on Morality, Harm, and Criminal Theory. Boston University Law Review, 83, 731-783.

46. WIPO (2001). WIPO Intellectual Property Handbook: Policy, Law and Use. World Intellectual Property Organisation Publication No. 489(E). Geneva: WIPO.

47. Hamilton-Smith, N. and Mackenzie, S. (forthcoming, 2010). The Geometry of Shadows: a Critical Review of Organised Crime Risk Assessments. Policing and Society. 